\title{
Přípravné vzdělávání a profesní rozvoj učitelů v Číně
}

\author{
Eliška Walterová, Vít Št’astný \\ Univerzita Karlova, Pedagogická fakulta, Ústav výzkumu a rozvoje vzdělávání
}

Redakci zasláno 1. 7. 2019 / upravená verze obdržena 3. 2. 2020 /

k uveřejnění přijato 10. 2. 2020

\begin{abstract}
Abstrakt: V současných diskuzích patří podpora učitelů jako klíčových aktérů kvalitního vzdělávání pro všechny ke globálním cílům udržitelného rozvoje. Cílem studie je představit systém vzdělávání a profesního rozvoje učitelů v kontextu vzdělávacích reforem v Číně, kde podpora učitelů je politickou prioritou vlády. Metodologicky je studie založena převážně na desk-research, má deskriptivně analytický charakter (srovnávání je implicitní). V centru pozornosti je kontinuita př́pravy a profesního rozvoje učitelů na národní (centrální) úrovni s exkurzemi do úrovně provinční a lokální. Soustřed'ujeme se na strukturu a kurikulum př́ípravného vzdělávání, přechod do praxe, profesní standardy a kariérní řád, na činnosti čínských učitelů ve škole a cyklické hodnocení jejich profesního rozvoje. V závěrečné diskusi jsou reflektovány charakteristické přístupy k učitelské profesi ve specifických podmínkách kulturně a typologicky odlišného vzdělávacího systému.
\end{abstract}

Klíčová slova: Čína, učitelé, standardy, reforma, kvalita ve vzdělávání

\section{Východiska, úvod do problematiky ${ }^{1}$}

V globalizovaném světě 21. století, jehož relativní rovnováha je ohrožována důsledky klimatických změn, geopolitických transformací a lokálních konfliktů překračujících hranice světových regionů či rozevíráním nůžek mezi skupinkou nejbohatších a „zbytkem“ populace, se vzdělávání stalo uznávanou politickou a ekonomickou prioritou. $\mathrm{V}$ konceptu udržitelného rozvoje (UNESCO, 2015, 2016) a jeho výhledů do budoucích desetiletí se dostává

1 Text je průnikem dílčích výstupů dvou výzkumných projektů. V projektu programu Progres Q17 Př́prava učitele a učitelská profese v kontextu vědy a výzkumu se zaměřujeme na diskurz o učitelské profesi vzhledem k proměnám úlohy školy v mezinárodním srovnání (dílčí úkol 1C). V rámci dlouhodobého projektu Školní vzdělávání v zahraničí, jehož výstupem jsou př́padové studie typologicky odlišných vzdělávacích systémů vydávané v nakladatelství Karolinum od roku 2008, připravují autoři článku monografickou studii o školním vzdělávání v Číně, v níž bude učitelská profese a příprava na ni zasazena do celkového rámce případové studie národního vzdělávacího systému.

https://doi.org/10.5817/PedOr2020-1-61 
zvýšené pozornosti podpoře učitelů jako klíčových aktérů zajištování kvalitního vzdělávání pro všechny. Globální cíl 4C definuje kvalifikované učitele jako důležité aktéry udržitelného rozvoje ve vzdělávání, soustřed'uje se na indikátory kvality, včetně forem podpory učitelů. Indikuje kontinuitu př́pravného vzdělávání a celoživotního učení jako významný faktor profesního rozvoje a kvality učitelů (UNESCO, 2016, s. 326-329).

Problémy vzdělávání a profesního rozvoje učitelů jsou jedním z nejfrekventovanějších témat rozsáhlých mezinárodních studií a srovnávacích výzkumů (např. mezinárodní šetření TALIS 2013, 2018), které přinášejí cenné údaje o proměnách a trendech vývoje této profesní skupiny, podmínkách a faktorech ovlivňujících její sociální status, determinujících kvalitu učitelů a jejich reálné působení ve školní realitě typologicky a kulturně blízkých i odlišných vzdělávacích systémů.

V tomto článku se zaměřujeme na vzdělávání a profesi učitelů v Číně, zemi s kulturní a vzdělávací tradicí, v níž je učitelství hluboce zakotveno jako respektovaná profese. Zaměření na kvalitu učitelů se v posledních dekádách stalo významnou součástí vzdělávacích reforem, podporujících transformaci čínské společnosti, ekonomickou prosperitu země a její postavení v globalizovaném světě.

Čína byla vybrána jako země kontrastní, jejíž vzdělávací systém a specifika nejsou v českém prostředí příliš známá, ač se kulturní kontakty, mobilita a spolupráce v oblasti vzdělávání rozvíjí, počty čínských studentů na našich univerzitách stoupají. Nutno dodat, že volbu tématu článku posílila aktuálnost, až naléhavost problémů spojených s nedostatkem učitelů provázející diskuse v českém prostředí, které vyústily až do návrhu sporné novely zákona o pedagogických pracovnících. Aktuální české diskuse učitelských skupin, odborníků i politiků se vztahují k nevyřešeným zásadním problémům učitelské profese. Díky politickým opatřením v posledních letech stoupají podhodnocené platy učitelů a dalších pedagogických pracovníkủ (měly by postupně dosáhnout výše odpovídající vysokoškolsky vzdělané profesi). Koncepční a systémové řešení však dosud chybí. Výrazným problémem je nedostatek kvalifikovaných učitelů ve školách obecně, v některých aprobacích dramaticky, což má vyřešit otevření učitelství pro odborníky-nepedagogy. Otázkou je, jaká bude kvalita školního vzdělávání v této nové situaci. Chybí kariérní řád, uvádění nových učitelů do praxe je nesystematické. Velmi rámcové standardy př́ípravného vzdělávání učitelů umožňují až neúnosnou kurikulární 
diverzitu. Chybějící koncepčně relevantní a funkční systém dalšího vzdělávání nahrazují dílčí projekty i nabídka neziskových organizací a agentur různé kvality. Tento článek považujeme tedy také za skromný příspěvek do aktuální diskuse. Chceme v něm mj. dokumentovat, že žádoucí systémová a komplexní řešení problémů učitelství by měla být prioritou vzdělávací politiky s dlouhodobými reálnými efekty v trvalé udržitelnosti a kvalitě učitelské profese.

Záměrem studie je poskytnout českým čtenářům vhled do vzdělávání a profesního rozvoje učitelů v Číně. Cílem je představit učitelskou profesi a její charakteristické rysy v kontextu tradice, kulturních specifik a společenských procesů $\mathrm{v}$ zemi, která $\mathrm{v}$ posledních desetiletích prochází bezprecedentní transformací. $V$ procesech proměn Číny sehrává významnou roli vzdělávání. Podpora učitelů jako klíčových aktérů zajištování jeho kvality patří k politickým prioritám vlády. Zaměříme se proto zejména na vládou řízené procesy, k nimž patři proměna struktury institucí vzdělávajících učitele, standardizace kurikula přípravného vzdělávání a kontinuita profesního rozvoje učitelů od hodnocení kvality výkonu profese ke kariérnímu postupu.

\section{Metoda $^{2}$}

Text článku představuje tematickou př́padovou studii vzdělávání a profese učitelů v jedné zemi (single case study), která obsahuje komparaci implicitně a může být využita jako předstupeň pro další komparace. Ve shodě s dalšími autory (Bray, Adamson, \& Mason, 2007; Steiner-Khamsi, 2010; Rabušicová \& Záleská, 2016, aj.) považujeme takové studie za užitečné a pro zainteresované čtenáře zajímavé. Ostatně i v současné komparativní literatuře jsou publikace tohoto druhu frekventované. ${ }^{3} \mathrm{~V}$ tematicky zaměřených př́padových studiích je třeba počítat s jistými limity při včleňování zkoumané problematiky do kontextu vzdělávacího systému dané země. $V$ našem př́padě proto považujeme za nezbytné odkazovat na historické a transformační procesy relevantní pro vývoj učitelského vzdělávání a profese v Číně.

2 Z důvodu omezeného rozsahu časopiseckého článku uvádíme informace v zestručněné podobě, podrobněji bude o způsobu získávání informací, zdrojových dat a ověřování jejich spolehlivosti pojednáno v připravované monografii (viz pozn. pod čarou 1).

3 Jde např́ílad o soubory případových studií vzdělávacích systémů (např. Hörner et al., 2015; Postlethwaite, 1995; Průcha, 2017) či průběžně aktualizované studie vzdělávacích systémů v Evropě (Eurydice, 2019). 
Předkládaná studie má převážně deskriptivně-analytický charakter. Základní metodou bylo studium a obsahová analýza primárních a sekundárních zdrojů informací (desk research).

Primární zdroje zahrnovaly (a) zákony vztahující se ke školnímu vzdělávání a k učitelům, další legislativní normy, rámcové standardy, vzdělávací programy, kurikulární rámce a programy, statistiky; (b) národní, provinční i lokální zprávy o stavu vzdělávání, programy a hodnoticí zprávy vzdělávacích institucí (univerzit a škol), inspekční zprávy, učebnice, informační stránky ministerstva školství, univerzit a škol; (c) mezinárodní statistiky a studie založené na kvantitativních údajích o indikátorech kvality vzdělávání (OECD, UNESCO, aj.). Čerpáno bylo i ze sekundárních zdrojů - monografií, přehledových a srovnávacích studií, článků v odborných časopisech, v menší míře pak i popularizujících článků a aktualit $\mathrm{v}$ novinách $\mathrm{v}$ elektronické i tištěné podobě. Při zpracování těchto dat jsme sledovali tematickou relevantnost pokrytí úrovně vzdělávacího systému (převažovala národní úroveň s limitovanými exkurzy do regionální a lokální úrovně). Zdá se, že vysoký počet titulů dostupných v anglickém jazyce odráží stále větší odborný a akademický zájem nejen o čínský vzdělávací systém, ale i o Čínu obecně.

Jako doplňkový zdroj informací byla využita vlastní empirická data získaná pozorováním a rozhovory při studijních pobytech autorů v reálném prostředí čínských univerzit a škol (2013-2019) i v rozhovorech s čínskými kolegy a studenty v rámci mobility a doktorského studia v anglickém programu. Při získávání těchto bylo využito osobních vazeb (v Číně nezbytných pro vstup do škol). Celkem bylo navštíveno šest škol různého stupně a typu, realizováno 17 polostrukturovaných rozhovorů (s čínskými řediteli, učiteli, rodiči a dvěma českými učiteli angličtiny pracujícími v Číně) a došlo i na neformální rozhovory při pracovních setkáváních a diskusích v navštívených institucích (univerzitách, centrech dalšího vzdělávání, školách). Tato data byla využita pro konkretizaci poznatků obecnějšího charakteru či pro ilustraci pojednávané problematiky, nicméně $\mathrm{z}$ důvodu omezeného rozsahu jsou v této studii explicitně využita jen sporadicky.

Limitujícím faktorem byl jazyk. Autoři nejsou sinologové, proto byly preferovány texty publikované $\mathrm{v}$ angličtině. Řada dokumentů je publikována v tomto jazyce a dostupná na webových stránkách čínského ministerstva školství, univerzit, čínských ambasád apod. U většiny základních legislativních dokumentů byl $\mathrm{k}$ dispozici také oficiální překlad do anglického jazyka. 
Méně dostupné texty, existující pouze v čínštině, byly překládány, jednak pomocí nástroje Google překladač s následným ověřením čínskými studentkami, případně byly těmito studentkami přímo přeloženy. $V$ reálném čínském edukačním prostředí byli zprostředkovateli čínští kolegové hovořící anglicky, kteří zároveň plnili roli tlumočníků v př́ípadě rozhovorů s aktéry nehovořícími anglicky.

Zde je třeba dodat, že četné anglicky psané publikace zabývající se čínským vzděláváním prezentují kritickoanalytické vnější pohledy, ovlivněné původem autora a mezinárodní (komparativistickou) zkušeností, zatímco „domácí čínští autoři mají pohledy konciliantnější s oficiální vzdělávací politikou. Přes výše uvedené limity se autoři článku snažili o maximální objektivnost a ověřování spolehlivosti převzatých dat a dodržení standardních postupů srovnávací pedagogiky tak, aby byly zřetelné procesy a trendy, které jsou v oblasti učitelského vzdělávání a profesního rozvoje klíčové a pro čínský vzdělávací systém a politiku charakteristické a specifické.

Článek nejprve čtenáře uvádí do kontextu problematiky učitelské profese v Č́ně a do historického vývoje př́pravy učitelů. Následuje popis současné podoby počátečního vzdělávání učitelů, na který navazují kapitoly k profesnímu rozvoji učitelů. V závěru jsou diskutovány prvky učitelské přípravy i profesního rozvoje charakteristické a specifické pro čínské prostředí.

\section{Kontext}

Kontext, ve kterém se vzdělávají a pracují čínští učitelé, je složitý a ovlivňovaný mnoha faktory. Aspirace na komplexnější a hlubší porozumění čínské realitě si mohou činit jen zkušení odborníci znalí historie a kulturních specifik, vnímaví k demografickým a sociálním problémům, s kritickým pohledem na čínskou politiku. Navíc pohledy české veřejnosti na Čínu se vyznačují značnou kontroverzností. Jsou ovlivňovány z různých zdrojů, nezř́́dka politicky motivované a mediálně prezentované, zpravidla však založené na povrchních znalostech a nedostatečných informacích.

Připomínáme, že Čína je rozlohou 9597 miliónů $\mathrm{km}^{2}$ třetí největší zemí světa a s počtem 1,4 mld. obyvatel nejlidnatější. Populace je extrémně nerovnoměrně rozložena. Neutěšené ekonomické a sociální podmínky nutí obyvatele nerozvinutých (zejména západních) oblastí k nelegální migraci do velkých měst za prací a výdělkem. Na území Číny žije 56 státem uznávaných 
etnických a národnostních skupin vedle 92 \% většinových Chanů. Mezi regiony jsou značné kulturní a etnické rozdíly. Čína je druhou největší ekonomikou světa, tvoří 15 \% světového HDP, avšak průměrné HDP na hlavu je pouze 7993 USD, což znamená až 77. místo na světě (Department of Economic and Social Affairs, 2018, s. 188, 201). Nárůst čínského HDP zahájily liberalizační reformy $\mathrm{v} 70$. letech.

Č́nská lidová republika (ČLR) je podle čl. 1 Ústavy ČLR definována jako „socialistický stát pod nadvládou (diktaturou) lidu vedený pracující třídou a založený na spojenectví pracujících a rolníků“. Opírá se o silný byrokratický stát a centrální vedení s vůdčí rolí Komunistické strany Číny (KSČí). V politické hierarchii je nejvyšším představitelem státu prezident, od roku 2018 s neomezenou dobou vládnutí. Dominantní role KSČ́i se uplatňuje na všech úrovních politického systému, přičemž orgány vyšší úrovně kontrolují činnost nižších. V Číně neexistuje legální opozice, oponenti režimu jsou jako disidenti stíháni a trestáni. Současnou Čínu lze tedy charakterizovat jako autoritativní režim využívající některé prvky demokracie (např. volby na nižších úrovních obcí). Unikátní je spojení tohoto politického systému s ekonomickým modelem neoliberálního kapitalismu (označovaného jako „socialismus s čínskými rysy“, viz např. Choi, 2011).

V současné Číně tvoří učitelé početnou socioprofesní skupinu (viz tabulka 1), jejíž funkce ve společnosti, vzdělávání a profesní kvality jsou předmětem zvýšeného politického zájmu. Podpora vzdělávání učitelů a jejich profesního rozvoje je oficiálně vyhlášenou prioritou vlády. Trend univerzitace vzdělávání učitelů a posílení prestiže učitelské profese je výsledkem déledobého transformačního procesu, jehož intenzivní fáze probíhá od přelomu milénia, výsledky se dostavují v posledních několika letech. V současné době získává vysokoškolský diplom $90 \%$ budoucích učitelů (Zhao, Zhou, \& Li, 2017, s. 163). Ten však nestačí pro získání jistého zaměstnání. Učitelé musí skládat další zkoušky a kontinuálně zlepšovat své profesní kompetence. Povinností učitelů je celoživotní vzdělávání, profesní růst a zdokonalování. Ověřování kvality a cyklické hodnocení učitelů, podléhající národním a provinčním standardům, provázejí profesní dráhu učitelů po celou dobu jejich aktivní služby. 
Tabulka 1

Počty učitelů pracujících na plný úvazek na jednotlivých úrovních vzdělávání (stav v srpnu 2019) a př́slušné počty žáků

\begin{tabular}{lccccc}
\hline Úroveň vzdělávání & Počet učitelů & $\%$ & Počet žáků & $\%$ & $\begin{array}{c}\text { Poměr } \\
\text { žák : učitel }\end{array}$ \\
\hline preprimární & 2581363 & $17 \%$ & 46564204 & $20 \%$ & $18: 1$ \\
\hline primární & 6102307 & $41 \%$ & 104125004 & $44 \%$ & $17: 1$ \\
\hline nižší sekundární & 3641178 & $24 \%$ & 46680415 & $20 \%$ & $13: 1$ \\
\hline vyšší sekundární všeobecné & 1814713 & $12 \%$ & 23794053 & $10 \%$ & $13: 1$ \\
\hline vyšší sekundární odborné & 833519 & $6 \%$ & 15552634 & $7 \%$ & $19: 1$ \\
\hline Celkem & 14973080 & $100 \%$ & 236716310 & $100 \%$ & $16: 1$ \\
\hline
\end{tabular}

Zdroj: National Bureau of Statistics of China (2019a, 2019b).

\section{Vývoj a transformace př́ípravného vzdělávání učitelů}

Budování vysokoškolského systému přípravného vzdělávání učitelů v Číně se vyznačuje výraznými specifiky. První instituce vzdělávající učitele vznikaly ve srovnání se západními zeměmi, včetně střední Evropy, relativně pozdě a ojediněle. Na počátku 20. století se učitelé mohli vzdělávat pouze na dvou vysokých školách, na učitelské koleji v Šanghaji a na Císařské koleji v Pekingu. V první polovině 20. století byly - v separaci od všeobecného a odborného vzdělávání - zakládány specializované školy (shifan) určené pro přípravu učitelů. Tyto tzv. normální školy vytvářely nezávisle studijní programy, které obsahovaly základ prípravy na profesi (pedagogiku, psychologii a obecnou didaktiku) a diferencovanou oborovou prŕípravu (Hayhoe, 2016).

Po vzniku Čínské lidové republiky (1949) procházela příprava učitelů peripetiemi dramatických historických změn. Pod vlivem maoismu byla zdůrazňována ideologická a politická dimenze profese na všech úrovních vzdělávání. V období Velké kulturní revoluce byla profese učitele degradována, instituce připravující učitele zavírány, jejich učitelé a studenti jako př́slušníci inteligence posíláni na převýchovu na venkov. Obrat ve směřování Číny k modelu socialistické společnosti s tržním mechanismem znamenal návrat ke konfunciánské tradici oceňující učitele jako vzor ctností a nositele znalostí (Hayhoe, 2016, s. 26) s novým důrazem na přínos vzdělávání pro ekonomickou prosperitu. Hierarchická soustava „normálních“ škol, připravujících výhradně 
učitele, fungovala až do konce 80. let. Byla považována za adekvátní pro řešení nedostatku učitelů v souvislosti se zaváděním povinné devítileté školní docházky, uzákoněné v roce 1973 (Zhou, 2014). Vzdělávání učitelů bylo bezplatné, ovšem s povinností 3-6 let (dle typu studia) vykonávat učitelskou profesi. Centrálně byly stanovovány kvóty studentů učitelství pro jednotlivé stupně vzdělávání, absolventi nastupovali na umístěnky. Ač probíhaly intenzivní vzdělávací reformy podporující ekonomický a sociální rozvoj Číny, učitelské vzdělávání zůstávalo stranou, bez politické a finanční podpory (Zhou \& Reed, 2005; Yang \& Wu, 1999). Monopol normálních škol limitovaných kvótami studentů a centrálně přidělovanými financemi dle počtu studentů spolu s rigidním kurikulem narušil po zanícených diskusích zákon o učitelích (Teachers' Law of the People's..., 1993) a dokument Regulace učitelské kvalifikace. Tyto dokumenty stanovily minimální úroveň vzdělávání a typy institucí, na nichž lze získat učitelskou kvalifikaci. Mezi tyto instituce byly zařazeny i neučitelské všeobecné koleje a multioborové univerzity. Zákon stanovil i další podmínky získaní statusu učitele.

V následující éře, označované jako post-shifan (Zhu \& Han, 2006, s. 68-72), se diverzifikovala struktura institucí připravujících učitele. „Normální“ střední školy pro učitele předškolního a primárního stupně se transformovaly na terciární učitelské koleje (srovnatelné s VOŠ v ČR, úroveň ISCED 5), jejich absolventi získávají akademické hodnosti. Učitelské koleje, dříve dvou- a tř́leté, byly transformovány na čtyřleté a postupně se staly „normálními“ univerzitami, působícími zejména $v$ méně rozvinutých provinciích s vysokou potřebou nových vysokoškolsky vzdělaných učitelů. Dřívější „normální“ univerzity rozšírily studijní programy o neučitelské obory, řada z nich se stala multioborovými výzkumnými univerzitami. Vůdčí pozici mají Pekingská normální univerzita a Východočínská normální univerzita v Šanghaji. Naopak, na multioborových univerzitách, které dříve učitelské obory neměly, byly založeny pedagogické fakulty nebo univerzitní katedry pedagogiky připravující učitele v konsekutivním modelu. Deset let po přijetí zákona o učitelích (Teachers' Law of the People's..., 1993) v roce 2003 zvýšila struktura terciárních institucí připravujících učitele, doplněná zavedením on-line studia učitelství, potenciál rozvoje vzdělanosti reflektující reálné potřeby vzdělávacího systému nejlidnatější země světa. $V$ roce 2015 celkový počet studentů v učitelských programech dosáhl 2,5 milionu (viz tabulka 2). 
Tabulka 2

Studenti učitelství ve vysokoškolském studiu (2015)

\begin{tabular}{ccc}
\hline Úroveň a typ vysokoškolské instituce & Počet přijatých & $\%$ \\
\hline 4leté koleje a univerzity & 1476598 & 60 \\
\hline 2-3leté koleje & 617660 & 25 \\
\hline 4leté koleje a univerzity pro dospělé & 280988 & 11 \\
\hline 4leté on-line koleje a univerzity & 46124 & 2 \\
\hline 2-3leté on-line koleje & 37435 & 2 \\
\hline Celkem & 2458805 & 100 \\
\hline
\end{tabular}

Zdroj: National Bureau of Statistics of China (2016), tab. 21-13, 21-14, 21-15, 21-16 a 21-17.

$\mathrm{V}$ roce 2015 , tedy po dvaadvaceti letech od implementace zákona o učitelích, získávali noví učitelé všech stupňů vzdělávání vysokoškolský diplom na transformovaných „normálních“ a multioborových vysokých školách. Menší část učitelů z praxe dosahovala vysokoškolské kvalifikace na kolejích a univerzitách pro dospělé, eventuálně on-line (viz tabulka 3 ).

Tabulka 3

Absolventi studia učitelství na vysokých školách v roce 2015

\begin{tabular}{ccc}
\hline Typ instituce & Počet absolventů & $\%$ \\
\hline 4leté koleje a univerzity & 366664 & 53 \\
\hline 2-3leté koleje & 189923 & 27 \\
\hline 2-3leté koleje a univerzity pro dospělé & 97029 & 14 \\
\hline on-line 4leté koleje a univerzity & 20614 & 3 \\
\hline on-line 2-3leté koleje & 16814 & 2 \\
\hline Celkem & 691044 & 100 \\
\hline
\end{tabular}

Zdroj: National Bureau of Statistics of China (2016), tab. 21-13, 21-14, 21-15, 21-16 a 21-17.

V turbulentní post-shifan éře byly řešeny nejprve strukturální a kvantitativní problémy související s dramatickým nedostatkem kvalifikovaných učitelů v povinném devítiletém vzdělávání a následným zvyšováním počtu žáků středních škol. Poté se pozornost obrátila k řízení a hodnocení kvality vzdělávání učitelů. Do ohniska pozornosti se dostává formulování nových standardů pro akreditace a evaluace institucí a studijních programů učitelství, profesních standardů všech kategorií učitelů a revitalizace učitelských 
certifikátů. Současně došlo k decentralizaci řízení učitelského vzdělávání, posílení role provincií a autonomie institucí vzdělávajících učitele při přijímání studentů, tvorbě kurikula a organizaci př́ípravného vzdělávání. Proces transformace struktury institucí otevřel více cest $\mathrm{k}$ učitelské profesi na vysokých školách (Zhao, Zhou, \& Li, 2017, s. 144).

\section{Současné přípravné vzdělávání učitelů}

Vzdělávání učitelů se tedy nyní v Č́ně realizuje na vysokých školách v duální institucionální struktuře: na „normálních“ univerzitách (dále NU) a na multioborových univerzitách. V Číně působí šest prestižních normálních univerzit, lokalizovaných $\mathrm{v}$ centrech významných provincií, které jsou př́mo řízené ministerstvem školství. ${ }^{4}$ Získávají mimořádnou finanční a politickou podporu, nabízejí učitelské i neučitelské obory, provádějí výzkum včetně pedagogického výzkumu, zavádějí a pilotně ověřují inovace, slouží jako modelové pro další univerzity označované jako lokální NU, které jsou spravovány lokálními orgány a plní důležité úkoly v okruhu své působnosti.

Od roku 1999 se na vysokých školách připravujících učitele platí školné s výjimkami studentů z venkovských a málo ekonomicky rozvinutých oblastí, kde je žádoucí, aby do studia učitelství vstupovali studenti z rodin s nízkým SES, kteří by na školné nedosáhli. V současné době se tedy v Číně připravují na vysokých školách učitelé všech stupňů vzdělávání, včetně učitelů předškolních zařízení a primárních škol, kteří získávají bakalářský titul nebo ekvivalent na normálních univerzitách. Postupně narůstá počet absolventů studia učitelství, kteří získávají magisterský titul.

\subsection{Modely učitelské př́ipravy}

V první dekádě 21 . století bylo zavedeno více modelů přípravného vzdělávání učitelů. Na lokálních NU vede k učitelství převážně integrovaný model, v němž je profesní a oborová příprava od počátku studia v rovnováze. Zvláštní pozornost je věnována reflektivní praxi a facilitaci přechodu do reálného prostředí školy. Konsekutivní model aplikují zejména selektivní multioborové univerzity, které připravují učitele středních škol v magisterském studiu ve struktuře $4+2$, kdy první čtyři roky se realizuje bakalářské studium oboru, poté se studenti rozhodují o učitelském či neučitelském směru. $V$ učitelském směru

4 Jsou to Beijing NU, East China NU, Northeast China NU, Central China NU, South West NU, Shanxi NU. První dvě jsou zařazeny mezi univerzity excelence. 
je 5. a 6. rok studia zaměřen na profesní přípravu, praxi a výzkum (viz níže). Ukončení př́ípravného vzdělávání není ještě finálním potvrzením kvalifikace. Absolventi musí nejméně rok vykonávat praxi pod vedením mentora a výcvik v centrech dalšího vzdělávání učitelů (CDV). Pak skládají zkoušky a mohou získat certifikát opravňující je pracovat ve škole jako učitelé.

Certifikace byla zavedena již v roce 1993, kdy byli testováni učitelé, kteří se vzdělávali na neučitelských školách, zatímco absolventi „normálních“ škol získávali učitelskou kvalifikaci automaticky. Od roku 2013 musí certifikát získat všichni noví učitelé. Certifikace (podrobněji níže) plní funkci „mostu“ mezi přípravným vzděláváním a zaměstnáním (Liu \& Zhang, 2019). Pro instituce poskytující př́ípravné vzdělávání má certifikace poskytovat zpětnou vazbu o kvalitě jejich absolventů i jich samotných. Je to svým způsobem „odložené" externí hodnocení kvality učitelské přípravy, které má standardní kritéria a je prováděno nezávislými organizacemi s licencí ministerstva školství (Zhao, Zhou, \& Li, 2017).

\subsection{Kurikulum prrípravného vzdělávání učitelů}

Současné kurikulum vychází z koncepce školního vzdělávání orientovaného na žáka a konceptu učitele coby reflektivního praktika. Tato koncepce nahradila unifikované centrálně předepisované kurikulum platné do 90. let. Pro 21. století byl vypracován a pilotně ověřen Rámcový standard př́pravného vzdělávání učitelů, který je spolu s profesními standardy všech kategorií učitelů klíčovým dokumentem pro tvorbu kurikula na univerzitách „normálních“ i multioborových, na nichž se vzdělávají učitelé.

Intenzivní fáze implementace nového kurikula učitelské přípravy je propojena s výzkumy, programy profesního rozvoje a perspektivou celoživotního vzdělávání učitelů.

Rámcové standardy učitelské přípravy (Liu \& Zhang, 2019, s. 342-343), stanovující povinnost realizovat výše uvedenou koncepci, obsahují tři základní komponenty: všeobecný základ, oborový komponent a profesní komponent. Součástí profesního komponentu je nejméně $10 \%$ praxe, jejíž součástí je výzkum. Instituce vzdělávající učitele vytvářejí své rámcové studijní programy, které respektují standard, avšak využívají relativní autonomie pro jejich konkretizaci. 
Pro ilustraci uvedeme př́klad kurikula př́pravného vzdělávání učitelů sekundární školy (viz tabulka 4, 5, a 6) na Zheijang Normal University. ${ }^{5}$ V aplikaci národního standardu klade tato univerzita důraz na profesní znalosti, kompetence a učitelské dovednosti. Pedagogický komponent má $25 \%$ kreditů, čtvrtinový podíl je přidělen všeobecnému základu a 50 \% oborovému studiu. V oborovém studiu má výrazný podíl oborová didaktika a oborová praxe (srov. tabulka 4, 5, a 6). Na univerzitě je zrrízeno Centrum pedagogické praxe, které provádí výcvik vyučovacích dovedností, organizuje mikrovyučování a pedagogickou praxi studentů ve školách. Pozornost si zaslouží to, že Centrum zodpovídá za praktickou prŕpravu studentů před vstupem na pedagogickou praxi ve školách. Hodnotí prrípravu studentů na vyučování, prŕístup k výuce, písemný projev, správnou výslovnost apod. Pokud student neprojde tímto hodnocením, není mu dovolena pedagogická praxe ve škole, bez níž nelze získat diplom. Student má povinnost 12 týdnů pedagogické praxe ve škole a tři týdny výzkumu. Kromě toho jsou součástí studia povinné oborové praxe a sociální praxe v místní komunitě (Yu, 2013).

Tabulka 4

Základní všeobecný modul

\begin{tabular}{|c|c|c|}
\hline Kategorie & Předměty & Kredity \\
\hline \multirow{7}{*}{ Povinné předměty } & Politická teorie* & 16 \\
\hline & Informační technologie & $4-6$ \\
\hline & Cizí jazyk & 12 \\
\hline & Tělesná výchova & 4 \\
\hline & Č́́nská literatura & 2 \\
\hline & Vyšší matematika a statistika & $3-10$ \\
\hline & Kariérové poradenství a příprava na zaměstnání & 2 \\
\hline \multirow{5}{*}{ Volitelné předměty } & Historie a kultura & \multirow{5}{*}{$6-12$} \\
\hline & Kultura a umění & \\
\hline & Ekonomie & \\
\hline & Věda a společnost & \\
\hline & Životní styl (well-being) & \\
\hline Celkem & & $49-64$ \\
\hline
\end{tabular}

5 Zheijang NU sídlí v hlavním městě provincie na východním pobřeží Číny, severně od provincie Šanghaj. Patř́ mezi 100 „top“ lokálních univerzit a je klíčová pro danou provincii. Nabízí učitelské i neučitelské programy na 18 fakultách. Pro představu: tato univerzita má 35000 studentů, učitelský sbor tvoří 2000 pedagogických a organizačních pracovníků. Univerzita přijímá zahraniční studenty a realizuje studijní programy také v angličtině. 
Zdroj: Normal Univerzity Zheijang, dokumentace dle Yu (2013), upraveno autory článku.

*Marxismus a maoismus, politický systém, principy a přednosti čínského politického modelu, etika učitelské profese v čínském systému.

\section{Tabulka 5}

\section{Oborový modul}

\begin{tabular}{|c|c|c|}
\hline Kategorie & Předměty & Kredity \\
\hline Úvod do studia oboru & & \multirow{2}{*}{$35-50$} \\
\hline Základy oboru & & \\
\hline \multirow{2}{*}{$\begin{array}{c}\text { Projektování a realizace kurikula } \\
\text { daného oboru }\end{array}$} & Oborová didaktika & \multirow{2}{*}{ minimálně 30} \\
\hline & Realizace kurikula ve vyučování & \\
\hline \multirow{4}{*}{ Praxe } & Zpracování diplomové práce & $6-10$ \\
\hline & Oborová praxe & $4-12$ \\
\hline & $\begin{array}{c}\text { Sociální praxe (aplikace politické } \\
\text { teorie)* }\end{array}$ & 2 \\
\hline & Vojenská teorie a výcvik ${ }^{* *}$ & 2 \\
\hline Celkem & & 79-106 \\
\hline
\end{tabular}

Zdroj: Normal Univerzity Zheijang, dokumentace dle Yu (2013), upraveno autory článku.

* Různé formy společenských aktivit, např. dobrovolnictví v sociálních službách, práce s dětmi v lokální komunitě, účast v soutěžích apod.

** Náhrada povinné vojenské služby (podobně jako u nás v době, kdy byla povinná vojenská služba a byla zařazena do vysokoškolského studia v náhradní formě).

\section{Tabulka 6}

\section{Pedagogický a profesní modul}

\begin{tabular}{ccc}
\hline Kategorie & Předměty & Kredity \\
\hline & Obecná pedagogika & 2 \\
& Pedagogická psychologie & 2 \\
Pedagogicko- & Psychologické poradenství na střední škole & 2 \\
psychologický základ & Učitelská etika & 2 \\
& Dějiny pedagogiky domácí a zahraniční & 2 \\
& Disciplíny pedagogiky & 2 \\
& Přednášky o vzdělávací reformě & 2 \\
& Teorie učitelské profese a profesního rozvoje & 2 \\
& Filozofie výchovy & 2
\end{tabular}




\begin{tabular}{|c|c|c|}
\hline Kategorie & Předměty & Kredity \\
\hline \multirow{4}{*}{$\begin{array}{l}\text { Školský management } \\
\text { a pedagogický výzkum }\end{array}$} & Řízení třídy & 2 \\
\hline & Organizace a vedení školy & 2 \\
\hline & Metody pedagogického výzkumu & 2 \\
\hline & $\begin{array}{l}\text { Výzkum standardů vyučovaných předmětů a učebních } \\
\text { materiálů střední školy }\end{array}$ & 2 \\
\hline \multirow{7}{*}{$\begin{array}{l}\text { Vyučovací dovednosti } \\
\text { a metody }\end{array}$} & Tvorba kurikula ve škole & 2 \\
\hline & Moderní technologie ve vzdělávání: teorie a aplikace & 3 \\
\hline & Jazykové dovednosti učitele & 1 \\
\hline & Dovednost psaní & 1 \\
\hline & Mikrovyučování a diagnóza výuky & 2 \\
\hline & Vyučovací strategie a plánování vyučování & 2 \\
\hline & Individualizace ve vyučování a její metody & 2 \\
\hline \multirow{3}{*}{ Pedagogická praxe } & Uvádějící praktikum & 2 \\
\hline & Vyučovací praxe & 7 \\
\hline & Výzkum vyučování & 1 \\
\hline Celkem & & 52 \\
\hline
\end{tabular}

Zdroj: Normal Univerzity Zheijang, dokumentace dle Yu (2013), upraveno autory článku.

\section{Profesní rozvoj učitelů}

\subsection{Vstup do profese}

Absolventi přípravného vzdělávání vstupují na otevřený trh práce. Místní správy a školské úřady, které organizují nábor učitelů, poskytují přehled o volných místech. Zájemci si mohou vybrat školu, kde je volné místo, a podat přihlášku školskému úřadu. Následně absolvují přijímací testy a pohovor, kterého se účastní zástupci školského úřadu a zástupci školy, zpravidla ředitel/ka a vedoucí skupiny daného předmětu, eventuálně další zástupci školy a místní správy. Uchazeč musí kromě testů předvést i ukázkovou hodinu a absolvovat motivační pohovor. Přijatí noví učitelé jsou zaměstnáni na pracovní smlouvu, kterou uzavírají zpravidla s místní správou, jen výjimečně přímo se školou. Smlouvy se dříve uzavíraly na dobu neurčitou, nyní musí učitel projít každoročním hodnocením, a pokud nesplní podmínky kvalifikace, může být propuštěn (OECD, 2016, s. 18). 


\subsection{Začínající učitel}

Absolvent náročného přípravného vzdělávání se ještě nestává kvalifikovaným. Pro získání tohoto statusu musí absolvovat ve škole jeden rok „zaškolování", který je součástí kariérního postupu. Program je zaměřen prakticky i teoreticky, soustřed'uje se na rozvoj kompetencí v oblasti metod výuky, ř́izení třídy a akčního výzkumu. Výcvik a podporu začínajícím učitelům poskytuje jednak škola formou mentoringu a shadowingu od zkušenějších učitelů, jednak formou pravidelné účasti v místních nebo univerzitních vzdělávacích centrech, která pořádají skupinové workshopy ve výzkumných učitelských týmech, nabízejí poradenství, organizují soutěže a odměňují úspěšné učitele. Začínajícím učitelům je ve školách přidělována výuka v ročnících, v nichž je učivo méně náročné. Mají sníženou administrativní zátěž, aby se mohli plně věnovat výuce a přípravě na ni. Nejpozději 60 dní před koncem zkušební doby musí absolvent získat učitelský certifikát (resp. atestaci).

Atestace, při níž učitel získává certifikát, je komisionální zkouška v závěru zkušebního období. Tato zkouška má jednotnou formu v celé Číně, obsah se liší podle stupně a typu vzdělávání, v němž chce učitel pracovat. Zkouška má písemnou a ústní část. $V$ písemném testu učitel prokazuje celkové osobnostní kvality, pedagogické a didaktické znalosti a dovednosti. $\mathrm{V}$ ústní části, která má formu strukturovaného rozhovoru, má učitel prokázat morální (politické) kvality, schopnost samostatného uvažování, řešení pedagogických a psychologických problémů, znalost vhodných přístupů k výuce a hodnocení žáků. Součástí je ukázková hodina před komisí. Ve vesnických oblastech často chybí vhodní a kvalifikovaní kandidáti na pozice učitelů, a tak se často musí tamní školy spokojit i s méně vhodnými kandidáty (Zhang, Ding, \& Xu, 2016, s. 18).

\subsection{Standardy práce učitele}

Celostátně platné standardy práce učitele byly vydány v roce 2011 jako závazné dokumenty mající přispět ke zkvalitnění vyučování. Jsou strukturovány do čtyř oblastí a 61 konkrétních požadavků na výkon učitelské profese. První oblast se vztahuje k výuce orientované na žáka, zahrnuje respektování vývojových specifik, péči a zájem o žáky a jejich potřeby, vytváření prostředí pro učení. Druhá oblast se vztahuje k učitelské etice, předpokládá, že učitel je pro žáky vzorem svým chováním a postoji, má být zodpovědný, trpělivý, optimistický, entuziastický, užívající vhodné jazykové prostředky. Třetí oblast se 
vztahuje $\mathrm{k}$ výuce, předpokládá obecné, didaktické a odborné znalosti a dovednosti, schopnost řídit třídu, udržovat kázeň a plánovat výuku. Čtvrtá oblast se vztahuje $\mathrm{k}$ celoživotnímu učení, předpokládá aktivní účast v dalším vzdělávání a kolektivním učení (Sato, 2017, s. 60-61).

\subsection{Kariérní řád}

Od čínských učitelů se očekává kontinuální zdokonalování a profesní růst. Kariérní řád je důležitým motivačním prvkem pro profesní rozvoj, který přispívá k minimalizaci fluktuace $\mathrm{v}$ učitelských oborech - čínští učitelé v profesi setrvávají 30 i více let. Kariérní řád, pilotovaný v Šanghaji na 120 školách již koncem 80. let, prošel jistými změnami. Nyní má pět stupňů (viz tabulka 7). Kromě toho existují čestné tituly pro excelentní a zasloužilé učitele. Na každém stupni je omezený počet pozic (například učitelů třetí úrovně je v Šanghaji jen 7 \%), a tak je postup na vyšší úrovně kompetitivní a vyžaduje řadu různých ocenění, publikací a aktivit. Pro postup v kariérním řádu podávají učitelé žádost k okresní komisi. Žádost obsahuje informace o aktuálním kariérním stupni učitele, jeho vzdělání, zapojení do výzkumů a jiných aktivit, seznam ocenění a úspěchů, informace o výsledcích jeho žáků a seznam publikací. Žádost nejprve schvaluje škola a ředitel postoupením žádosti komisi dává najevo svůj souhlas s tím, že uchazeč splňuje potřebné náležitosti. Na okresní úrovni zasedá expertní komise složená zejména ze zkušených a úspěšných učitelů vedoucích předmětové komise na různých školách, kteří žádosti posuzují a rozhodují o postupu učitele na vyšší stupeň (Sato, 2017, s. 110).

Učitelé vyšších tří stupňů musí poskytovat mentoring začínajícím a méně zkušeným učitelům. Pro postup do vyšších stupňů je také požadována realizace aplikovaného pedagogického výzkumu (viz níže) a přednost pro povýšení mají ti uchazeči, kteří mají zkušenost s výukou ve vesnických oblastech nebo kteří různými způsoby podporují své kolegy z chudších západních čínských provincií (The National Center on Education and the Economy, 2016, s. 13). 


\section{Tabulka 7}

\section{Kariérní rád: požadavky na vstup do vyššího stupně}

\begin{tabular}{|c|c|}
\hline Stupeň & Požadavky \\
\hline $\begin{array}{l}\text { Učitel } \\
\text { třetí } \\
\text { úrovně }\end{array}$ & $\begin{array}{l}\text { 1) na základní úrovni zvládá vyučovací principy a metody a vedení žáků; } \\
\text { 2) má základní znalosti pedagogiky, psychologie a didaktiky; } \\
\text { 3) má associate degree nebo absolvoval secondary normal school, zaškolovací } \\
\text { program a složil závěrečnou zkoušku. }\end{array}$ \\
\hline $\begin{array}{l}\text { Učitel } \\
\text { druhé } \\
\text { úrovně }\end{array}$ & $\begin{array}{l}\text { 1) dovedně zvládá vyučovací principy a metody a relativně dobře organizuje svoji } \\
\text { práci; } \\
\text { 2) zvládá základní znalosti pedagogiky, psychologie a didaktiky, prokazuje } \\
\text { oborově didaktickou expertnost; } \\
\text { 3) zvládá metodologii akčního výzkumu, snaží se aktivně rozvíjet výzkum } \\
\text { vyučování; } \\
\text { 4) má magisterský nebo bakalářský titul, absolvoval zaškolovací program } \\
\text { (probationary period) a složil závěrečnou zkoušku, nebo má associate degree } \\
\text { a pracoval jako učitel třetí úrovně dva a více let, nebo absolvoval secondary } \\
\text { normal school (střední pedagogickou školu) a sloužil jako učitel třetí úrovně } \\
\text { alespoň tř̌i roky. }\end{array}$ \\
\hline $\begin{array}{l}\text { Učitel } \\
\text { první } \\
\text { úrovně }\end{array}$ & $\begin{array}{l}\text { 1) má schopnost správně vyučovat žáky a dobře zvládá své pracovní povinnosti; } \\
\text { 2) má solidní teoretické znalosti a expertízu ve svém vyučovaném oboru, je } \\
\text { zkušený ve využívání vyučovacích dovedností a podává dobré výkony; } \\
\text { 3) má určitou schopnost organizovat a vést akční výzkum, umí vykonávat některé } \\
\text { úkoly spojené s akčním výzkumem; } \\
\text { 4) přispívá k vedení učitelù druhé a třetí úrovně, pomáhá jim zlepšovat jejich } \\
\text { didaktické schopnosti a dovednosti; } \\
\text { 5) má doktorský nebo magisterský titul a pracoval jako učitel druhé úrovně } \\
\text { nejméně dva roky, nebo má bakalářský titul nebo associate degree a pracoval } \\
\text { jako učitel druhého stupně alespoň } 4 \text { roky, nebo je absolventem secondary } \\
\text { normal school a pracoval jako učitel druhé úrovně alespoň } 5 \text { let. }\end{array}$ \\
\hline $\begin{array}{l}\text { Zkušený } \\
\text { učitel }\end{array}$ & $\begin{array}{l}\text { 1) efektivně vyučuje a vede žáky s ohledem na jejich věk a zázemí, jeho výuka } \\
\text { přináší vynikající výsledky; } \\
\text { 2) má solidní teoretické znalosti a expertnost ve svém vyučovaném oboru, je } \\
\text { zkušený učitel a podává vynikající výkony; } \\
\text { 3) má schopnosti organizovat a vést akční výzkum, přinesl do vyučování či } \\
\text { kurikula významné inovace; } \\
\text { 4) je kvalifikovaný leader, hraje důležitou roli při vedení učitelů první, druhé } \\
\text { a třetí úrovně; } \\
\text { 5) má doktorský titul a pracoval jako učitel první úrovně alespoň } 2 \text { roky, nebo má } \\
\text { magisterský, bakalářský titul nebo associate degree a pracoval jako učitel prví } \\
\text { úrovně déle než } 5 \text { let. } \\
\text { Učitelé v městských oblastech by měli mít alespoň jeden rok pracovních } \\
\text { zkušeností jako učitelé ve vesnických oblastech. }\end{array}$ \\
\hline
\end{tabular}




\begin{tabular}{|c|c|}
\hline Stupeň & Požadavky \\
\hline $\begin{array}{l}\text { Zkušený } \\
\text { učitel - } \\
\text { profesor }\end{array}$ & $\begin{array}{l}\text { 1) má zapálení pro profesi učitele a vysoké kariérní aspirace; mnoho let učitelské } \\
\text { praxe a výjimečné schopnosti vést mládež; } \\
\text { 2) mistrovsky zvládá kurikulum, má komplexní odborné znalosti, ve výuce } \\
\text { předmětu dosahuje vynikajících výkonů pomocí skvělého didaktického } \\
\text { přístupu; } \\
\text { 3) má schopnost organizovat a řídit akční výzkum, přinesl inovace do výuky nebo } \\
\text { kurikula, které jsou široce využívány a považovány za příkladné; } \\
\text { 4) vede jiné učitele, je velmi známý a svými kolegy uznávaný jako odborník } \\
\text { na vzdělávání; } \\
\text { 5) má bakalářský nebo vyšší titul a pracoval jako zkušený učitel více než pět let. }\end{array}$ \\
\hline
\end{tabular}

Zdroj: OECD, 2016, s. 21 (upraveno autory článku).

\subsection{Výzkumné aktivity učitelů}

Zvláštní pozornost v profesní profilaci učitelů je věnována výzkumu, zejména výzkumu akčnímu. Studijní programy učitelství obsahují v profesním komponentu výzkum jako jeden z povinných předmětů. Intenzita akčních výzkumů ve školách se zvýšila v posledních dvou desetiletích, což je přičítáno implementaci kurikulární reformy po roce 2001, která předznamenala zásadní změny v roli učitele a zdůraznila propojení teorie s praxí (Bai, 2009, s. 144). Akční výzkumy jsou finančně podporovány v provinciích školskými komisemi a jejich realizace je jedním z kritérií hodnocení kvality školy (Zhang, Ding, \& Xu, 2016, s. 17). Akční výzkumy menšího rozsahu, které řeší komunitní problémy dané školy, realizují sami její učitele či učitelské skupiny, na výzkumech většího rozsahu se podílí více škol, v jejich týmech jsou i externí odborníci a výzkumníci z univerzit, kteří pomáhají s identifikací problému, formulací výzkumných otázek a volbou výzkumných nástrojů. Společně navrhují praktická opatření a inovace. Příklady takových projektů lze nalézt v řadě publikací (Yuan \& Burns, 2017; Zhang, Ding, \& Xu, 2016 aj).

Ambiciózní požadavek realizovat akční výzkumy nejsou ovšem schopni plnit všichni učitelé. Dle průzkumu Beijing Normal University uvádějí učitelé jako nejčastější problémy a důvody, proč se aplikovanému výzkumu nevěnují, nedostatek času a nedostatečné výzkumné kompetence (Gu, Ma, \& Teng, 2017, s. 184). Také v rozhovorech autorů tohoto článku s čínskými učiteli byla povinnost realizovat výzkumy reflektována kriticky jako požadavek důležitý pro kariérní postup, který učitelé formálně plní, avšak bez výrazného efektu na zlepšení výuky. Podobně v přehledové studii Bai (2009) upozorňuje na stoupající kvantitu výstupů akčních výzkumů, ale uvádí pochybení v konceptech, metodologii i interpretaci výsledků a absenci originality. 


\subsection{Další vzdělávání učitelů}

Nutnou podmínkou pro postup do vyšších stupňů kariérního systému je další vzdělávání. Všichni učitelé primárních a sekundárních škol musí každých pět let absolvovat 360 hodin profesního vzdělávání (OECD, 2016, s. 19). Programy dalšího vzdělávání učitelů (dále DVU) se vytvářejí na více úrovních. Na národní úrovni je to ministerstvo školství, které ve speciálním oddělení připravuje Národní program vzdělávání učitelů, na úrovni provincií zodpovídají za programy DVU provinční školské komise, jejich realizaci provádějí specializovaná centra DVU. Tak např̀ v Šanghaji je to oddělení lidských zdrojů CDV učitelů a Institut pro didaktický výzkum, zřízený Šanghajskou municipální komisí. Také na úrovni okresů jsou organizována pravidelná školení pro školy, které spadají do příslušné správní oblasti.

Př́ikladem jedné z (u nás spíše neobvyklých) forem DVU je „otevřená hospitace," kterou měl možnost pozorovat druhý autor tohoto článku. Jejím cílem bylo sdílení zkušeností a zpětná vazba pro 30 učitelů z celého městského obvodu v Šanghaji. Učitelka navštívené školy připravila a vedla hodinu výtvarné výchovy, celý průběh se natáčel na video pro pozdější analýzy. Po skončení hodiny provedla učitelka autoreflexi, poté následovaly komentáře ředitelky a učitelky z centra pro vzdělávání učitelů, následovala diskuse zúčastněných učitelů. DVU probíhá také na úrovni školy, kde je organizované učitelskými skupinami, které jsou formou spolupráce v učitelských sborech, do níž se promítá pro čínskou kulturu a společnost charakteristický kolektivismus.

\subsection{Učitelské skupiny}

Učitelské skupiny existují na školách v několika formách. Skupiny pro př́ípravu výuky (beike-zu) sdružují učitele určitého předmětu, společně připravují výuku ve svém předmětu, diskutují metody a formy realizace, komentují a společně výuku hodnotí. Nezř́́dka se účastní i ředitel/ka nebo jiná osoba z vedení školy. Výstupem práce skupiny bývá doporučení žádoucího způsobu výuky v daném předmětu na škole (Paine \& Fang, 2007). Učitelské výzkumné skupiny jsou specifickou formou profesního učení, jejich zaměření je relativně široké, např. revize školního kurikula, příprava testů pro žáky nebo koordinace mimotřídních aktivit apod. Hlavní náplní jejich činnosti je akční výzkum. Takové skupiny vedou zpravidla úspěšní učitelé zařazení do vyšších kariérních stupňů. 


\subsection{Pracovní náplň učitelů a specifika vykonávání profese}

Výuka spolu s akčními výzkumy a dalším vzděláváním představují v pracovní náplni čínských učitelů činnosti podstatné pro vykonávání profese. Výzkum, který by se zabýval alokací času věnovaného jednotlivým pracovním činnostem učitelů v celé Číně, bohužel není $\mathrm{k}$ dispozici. Dílčí údaje lze nalézt ve výzkumu TALIS, který však byl omezen pouze na provincii Šanghaj, jež patří $\mathrm{k}$ edukačně nejrozvinutějším. Za pozornost stojí, že v mezinárodním srovnání (TALIS 2013+) 6 šanghajští učitelé věnují výuce ve třídě v průměru 13,8 hodin týdně, což je nejméně ze všech zúčastněných zemí (průměr 19,2, v ČR 17,8), avšak celkový počet hodin pro školu 39,7 byl mírně nadprůměrný (průměr TALIS 38,5, ČR 39 hodin týdně). Mimovýukový čas využívají čínští učitelé k opravám domácích úkolů $(7,9$ hod týdně, v ČR pouze 4,5), doučování a poradenství pro žáky 5,1 hodin (ČR 2,2) týdně, účastní se sdíleného vedení školy (3,3 hodin týdně), ${ }^{7} 4,1$ hodin týdně komunikují a spolupracují s kolegy ${ }^{8}$ (Zhang, 2017, s. 43-45). Povinností všech učitelů (včetně těch zkušených) je vypracovávat písemné př́pravy na každou vyučovací hodinu, které podléhají kontrole skupinových vedoucích. Zkušenější učitelé vykonávají pozici třídního učitele (banzhuien) s příslušnými povinnostmi, včetně návštěv rodin žáků a organizování volnočasových aktivit i během víkendu (Liu \& Zhao, 2013, s. 233). Charakteristickým rysem kolektivismu, který se odráží i v požadované transparentnosti vyučování a dalších činností učitele, je otevřenější fyzické prostředí ve školách, které umožňuje nadřízeným a kolegům nahlížet do tříd, o čemž se autoři mohli přesvědčit v každé ze šesti navštívených škol, dále pravidelná shromáždění celé školy s příslušnými rituály a veřejnými komentáři k práci žáků, tříd i učitelů.

\subsection{Hodnocení učitelů}

Hodnocení učitelů v Číně je od roku 2009 navázáno na systém odměňování a má být formativní. Variabilní složka platu je v kompetenci školy, ale řídí se obecnými pokyny vydávanými centrálně a modifikovanými na úrovni provincií. Školy mohou jednotlivým kritériím přidělit různou váhu. Na celkovém

6 Šanghaj se účastnila až návazného šetření TALIS 2013+, které OECD zorganizovalo dodatečně pro čtyři země/ekonomiky, data byla sbírána až v první polovině roku 2015, avšak s využitím identických metodologických postupů jako ve vlně šetření 2013 (viz Zhang, 2017, s. 2).

7 Tyto činnosti jsou nutné pro organizaci práce školy (čínské školy mají ve srovnání s českými mnohonásobně vyšší počty žáků a tříd).

8 Skupiny učitelů vyučují v jednom ročníku v paralelních tř́́dách jeden předmět (čínští učitelé mají zpravidla jednooborové aprobace). 
posouzení práce učitele se podílí kromě ředitelů další lidé, např vedoucí učitelských skupin, představitelé místní komunity, eventuálně rodiče a žáci. Oceňovány jsou nejen pravidelné činnosti a vzorné plnění povinností, ale zvláštní finanční odměny dostávají učitelé, kteří byli úspěšní v soutěžích na provinční a národní úrovni, či učitelé, jejichž žáci byli úspěšní v oblíbených soutěžích znalostí a talentů nebo u přijímacích zkoušek na prestižní vysoké školy.

Mzdu čínského učitele tvoří čtyři složky (Elmer \& Crothall, 2016; OECD, 2016, s. 21; Pedro, 2017):

- základ, odvozený od kariérního stupně s příplatkem za počet odpracovaných let, což je v průměru 40 \% celkového platu;

- výkonová složka, která se liší v regionech dle ekonomické úrovně a cen plus bonusy za přesčasové hodiny, třídnictví, dobré výsledky žáků apod.;

- sociální benefity (penzijní připojištění, úrazové pojištění, příspěvek na bydlení aj.);

- další př́íplatky (např. za práci ve znevýhodněných a venkovských oblastech) stanovované centrálně.

Celkově jsou platy učitelů v Číně v mezinárodním srovnání spíše podprůměrné ${ }^{9}$ a neodpovídají vysokým nárokům na výkon profese. Ta však je považována za prestižní, učitelé v ní setrvávají dlouhodobě a v mezinárodním srovnání patří učitelská profese v Číně k nejméně feminizovaným (OECD, 2017, s. 395). Zároveň jsou v platech čínských učitelů značné rozdíly z důvodů pohyblivé složky a významně se liší $v$ jednotlivých provinciích. Neméně problematické jsou také rozdíly v platech učitelů ve venkovských a městských školách, které i navzdory různým př́platkům či výhodám pro učitele na venkově zůstávají vysoké a jsou považovány za jednu z př́čcin strukturálního nedostatku učitelů v těchto oblastech. Ojedinělé zde není ani porušování zákonných požadavků, které stanoví, že platy učitelů v povinném vzdělávání by neměly být nižší než průměrný plat místních státních zaměstnanců, a to i navzdory speciálním dotačním programům a titulům centrální vlády (Xuehui, 2018).

9 Podle dostupných srovnatelných údajů z šetření Doltona a kol. (2018) činil v roce 2018 průměrný roční plat čínského učitele (přepočtený na paritu kupní síly) 1221 USD, tj. cca 23200 Kč měsíčně (v ČR to bylo 1886 USD, tj. cca 35800 Kč měsíčně). 


\section{Diskuse a závěrečná rozvaha}

Tento článek zaměřený na učitele jako významné aktéry zkvalitňování vzdělávání pro všechny poskytl primární vhled do problematiky indikované jako součást globálních cílů udržitelného rozvoje $\mathrm{v}$ podmínkách vzdělávacího systému jedné země. Volba Číny, země s výraznými kulturními, politickými a demografickými specifiky a vnitřní diverzitou podmínek vzdělávání, byla odůvodněna jejím vzrůstajícím geopolitickým významem, zintenzivňujícími se kulturními kontakty a vzdělávací mobilitou mezi ČR a ČLR na jedné straně, potřebou vhledu do dosud u nás nezkoumaných endogenních procesů v oblasti vzdělávání a vzdělávací politiky vůči učitelům a podpoře jejich profesního rozvoje v Číně na straně druhé. Text byl koncipován jako tematická př́padová studie deskriptivně analytického typu, které neobsahuje explicitní komparace (s několika dílčími výjimkami). Snažili jsme přibližit procesy, vazby a priority uvnitř zkoumaného vzdělávacího systému, které mohou být relevantní a poučné pro vzdělávací systémy a politiky v jiných zemích.

V tomto ohledu stojí za pozornost několik zjištění, která chceme zdůraznit. Ačkoliv historický vývoj systému učitelského vzdělávání v Číně byl chronologicky opožděný ve srovnání s rozvinutými západními zeměmi, jeho rozvoj během dvou desetiletí cílených reforem a transformací dosáhl úrovně univerzitace srovnatelné s edukačně rozvinutými zeměmi. Přijímané strukturální reformy a fáze transformace se odvíjely zprvu odděleně od centrálně formulovaných politických cílů determinovaných ekonomickými potřebami země. Poněkud opožděný byl důraz na kvalitu přípravy učitelů a profesní rozvoj, což způsobilo dočasnou stagnaci.

Pozitivním př́nosem ke zkvalitňování přípravy učitelů a profesního rozvoje byla decentralizace ř́zení, která však byla spojená s koncepčně sjednocenými standardy přípravného vzdělávání, profesními standardy a kariérním řádem. ${ }^{10}$ Otevření prostoru pro výzkumné aktivity učitelů, stanovení povinnosti dalšího vzdělávání s cyklickým hodnocením kvality učitelů v praxi a jeho spojení $\mathrm{s}$ kariérním postupem se jeví jako logické, avšak zůstává v této fázi výzkumu na úrovni deskriptivní analýzy politických opatření a formálních dokumentů, doplněných dílčími exkurzy do reality. Vyžaduje hlubší prozkoumání a doplnění relevantních empirických dat z reálného fungování systému

10 Např́klad poslední ze jmenovaných nástrojů byl u nás hojně diskutován, avšak na finální podobě kariérního řádu pro učitele se aktéři vzdělávací politiky neshodli, a tak v r. 2017 došlo k jeho odložení, jak se zatím zdá, na dobu neurčitou. 
vzdělávání a profesního rozvoje učitelů v celé Číně, které dosud nebyly k dispozici ani v mezinárodních komparacích TALIS, jichž se zatím účastní pouze provincie Šanghaj (OECD, 2019).

Je rovněž potřeba čtenáře znovu upozornit, že uvedené prezentované skutečnosti týkající se přípravného vzdělávání učitelů a jejich profesního rozvoje nejsou ve stejné míře a kvalitě realizovány na celém území Číny. Jak píše Ringen (2018, s. 99-100), v tak složitém a byrokratizovaném systému, jakým je čínská veřejná správa, stojí centrální vládu velké úsilí zajistit, aby politika byla sledována a implementována. Implementace naráží také na odlišnosti podmínek a charakteru jednotlivých lokalit v rámci Číny. Například kariérní řád tak může snadno fungovat v Šanghaji (kde byl i pilotován) s dostatečným množstvím uchazečů o práci učitele, avšak $\mathrm{v}$ praxi by jeho funkčnost, např́klad v izolovaných vesnických oblastech, byla značně limitována z důvodu nedostatku pracovních sil. I proto jsou v kariérním řádu institucionálně ukotveny výhody pro učitele, kteři rozvoj v těchto méně rozvinutých oblastech podporují, byt' jejich dopady dosud spíše jen mírnily dosavadní trendy jednosměrné migrace do ekonomicky rozvinutějších oblastí, včetně migrace kvalifikovaných učitelů. Toto opatření na podporu mobility učitelů do oblastí s jejich nedostatkem by mohlo být inspirativní i pro kariérní ráa v našich podmínkách, nebot’ některé české regiony (např. Karlovarský nebo Středočeský kraj, viz Zatloukal et al., 2019, s. 53) se potýkají s chronickým nedostatkem kvalifikovaných učitelů.

V čínském kontextu je evidentní systematičnost a cílevědomost podpory učitelů zejména na úrovni politického centra a legislativy. Učitelská profese má vysoký status, autorita učitelů není zpochybňována ani rodiči, ani žáky, což však může hraničit až s nekritickou poslušností vůči autoritám a vést k petrifikaci stávajícího režimu. Je otázkou současnosti a výzvou budoucnosti, zda pro další rozvoj Číny bude tvrdá práce učitelů, ač politicky podporovaná, zároveň také ostře monitorovaná, $\mathrm{v}$ déledobé perspektivě zárukou samostatnosti a kreativity, tak potřebné pro vzdělávání a život v 21 . století.

Přes metodologické a jazykové limity, kterých jsme si jako autoři této studie vědomi, se domníváme, že náš text čtenáře zaujme nejen svým tématem a zaměřením na u nás méně známý systém učitelského vzdělávání a profesního rozvoje, ale také přispěje $\mathrm{k}$ aktuální diskusi o řešení problémů nedostatku učitelů, předpokládaných profesních kvalitách a podpoře práce učitelů. 


\section{Literatura}

Bai, Y. (2009). Action research localization in China: Three cases. Educational Action Research, $17(1), 143-154$.

Bray, M., Adamson, B., \& Mason, M. (Eds.). (2007). Comparative education research. Approaches and methods. Hong Kong: CERC.

Department of Economic and Social Affairs (2018). Statistical Yearbook 2018 edition: Sixty-first issue. New York: United nations. Dostupné z: https://unstats.un.org/unsd/publications/ statistical-yearbook/files/syb61/syb61.pdf

Dolton, P., Marcenaro-Gutierrez, O., de Vries, R., \& She, P. (2018). 2018 Global teacher status index. London: Varkey Gems Foundations. Dostupné z https://www.varkeyfoundation.org/ media/4790/gts-index-9-11-2018.pdf

Elmer, K., \& Crothall, G. (2016). Over-worked and under-paid. The long-running battle of China's teachers for decent work. Hong Kong: China Labour Bulletin. Dostupné z www.clb.org.hk/ sites/default/files/Teachers\%20final.pdf

Eurydice (2019). National education systems in Europe. Dostupné z https://eacea.ec.europa.eu/ national-polices/eurydice/national-description_en

Gu, M., Ma, J., \& Teng, J. (2017). Portraits of Chinese schools. Beijing: Springer.

Hayhoe, R. (2016). The idea of the normal university of education: Implication for a Confucian pedagogy. In J. Lee \& C. Day (Eds.), Quality and change in teacher education: Western and Chinese perspectives (s. 215-229). Dordrecht: Springer.

Hörner, W., Döbert, H., Reuter, L. R., \& von Kopp, B. (Eds.). (2015). The education systems of Europe. Cham: Springer International Publishing Switzerland.

Choi, Y. (2011). The evolution of "Socialism with Chinese characteristics": Its elliptical structure of socialist principles and China's realities. Pacific Focus, 26(3), 385-404.

Liu, B., \& Zhang, R. (2019). Teacher education in China. In K. G. Karras \& C. C. Wolhuter (Eds.), International handbook of teacher education worldwide (s. 327-346). Nicosia: HM Studies and Publishing.

Liu, S., \& Zhao, D. (2013). Teacher evaluation in China: Latest trends and future directions. Educational Assessment, Evaluation and Accountability, 5(3), 231-250.

National Bureau of Statistics of China (2016). China statistical yearbook 2016. Dostupné z www. stats.gov.cn/tjsj/ndsj/2016/indexeh.htm

National Bureau of Statistics of China (2019a). Number of female educational personnel and fulltime teachers of schools by type and level. Dostupné z http://en.moe.gov.cn/documents/ statistics/2018/national/201908/t20190812_394239.html

National Bureau of Statistics of China (2019b). Number of students of formal education by type and level. Dostupné z http://en.moe.gov.cn/documents/statistics/2018/ national/201908/t20190812_394229.html

OECD (2016). Education in China: A snapshot. Dostupné z www.oecd.org/china/Education-inChina-a-snapshot.pdf.

OECD (2017). Education at a glance 2017: OECD indicators. Paris: OECD Publishing. Dostupné z http://dx.doi.org/10.1787/eag-2017-en

OECD (2018). Learning Framework for 2030. Paris: OECD Publishing. 
OECD (2019). TALIS 2018 Results (volume I): Teachers and school leaders as lifelong learners. Paris: OECD Publishing.

Paine, L., \& Fang, Y. (2007). Supporting China's teachers. In E. Hannum \& A. Park (Eds.), Education and reform in China (s. 173-192). New York: Routledge.

Pedro, K. (2017, 24. července). How much are Chinese teachers' salaries in China? QUORA. Dostupné z https://www.quora.com/How-much-are-Chinese-teachers-salaries-in-China

Postlethwaite, T. N. (Ed.). (1995). International encyclopedia of national systems of education. Oxford: Pergamon.

Průcha, J. (2017). Vzdělávací systémy v zahraničí. Praha: Wolters Kluwer ČR.

Rabušicová, M., \& Záleská, K. (2016). Metodologické otázky srovnávací pedagogiky: podněty pro koncipování komparativních studií. Pedagogická orientace, 26(3), 346-378.

Ringen, S. (2018). Perfektní diktatura: Čína ve 21. století. Praha: Academia.

Sato, M. (2017). Empowered educators in China: How high-performing systems shape teaching quality. San Francisco: Jossey-Bass.

Steiner-Khamsi, G. (2010). The politics and economics of comparison. Comparative Education Review, 54(3), 323-342.

Teachers' law of the People's Republic of China (1993, 31. ř́jna). Dostupné z http://en.moe.gov. cn/Resources/Laws_and_Policies/201506/t20150626_191389.html

The National Center on Education and the Economy (2016). Empowered educators: Shanghai: Culture, policy and practice. Dostupné z http://ncee.org/wp-content/uploads/2017/02/ ShanghaiCountryBrief.pdf

UNESCO (2015). Rethinking education: Towards of a global common good. Paris: UNESCO Publishing.

UNESCO (2016). Education for people and planet: Creating sustainable future for all. Paris: UNESCO Publishing.

Xuehui, A. (2018). Teacher salaries and the shortage of high-quality teachers in China's rural primary and secondary schools. Chinese Education \& Society, 51(2), 103-116.

Yang, D., \& Wu, J. (1999). Some issues in the reform and development of teacher education in China. Teacher Development, 3(2), 157-172.

Yu, T. (2013). Teacher education in China: Current situation and related issues. Zheijang Normal University. Dostupné $\mathrm{z}$ www.uta.fi/cerec/educationandresearch/ChinaEduLecture/ Teacher\%20Education\%20in\%20China.pdf

Yuan, R., \& Burns, A. (2017). Teacher identity development through action research: A Chinese experience. Teachers and Teaching, 23(6), 729-749.

Zatloukal, T., et al. (2019). Kvalita a efektivita vzdělávání a vzdělávací soustavy ve školním roce 2018/2019: Výroční zpráva České školní inspekce. Praha: ČŠI.

Zhang, M. (Ed.). (2017). Professionalism and excellence. A brief report of the Teaching and Learning International Survey 2015 in Shanghai. Shanghai TALIS Center: Shanghai.

Zhang, M., Ding, X., \& Xu, J. (2016). Developing Shanghai's teachers. Washington: NCEE.

Zhao, P., Zhou, J., \& Li, Q. (2017). Teacher education. In W. J. Morgan, Q. Gu, \& F. Li (Eds.), Handbook of education in China (s. 140-168). Cheltenham, Northampton: Edvard Elgar Publishing.

Zhou, J. (2014). Teacher education changes in China 1974-2014. Journal of Education for Teaching, 40(5), 507-523. 
Zhou, J., \& Reed, L. (2005). Chinese government documents on teacher education since 1980s. Journal of Education for Teaching, 31(30), 201-213.

Zhu, X., \& Han, X. (2006). Reconstruction of the teacher education system in China. International Education Journal, 7(1), 66-73.

\section{Autoři}

Prof. PhDr. Eliška Walterová, CSc., Univerzita Karlova, Pedagogická fakulta, Ústav výzkumu a rozvoje vzdělávání, Myslíkova 7, 11000 Praha 1, e-mail: eliska.walterova@pedf.cuni.cz

PhDr. Vít Št’astný, Ph.D., Univerzita Karlova, Pedagogická fakulta, Ústav výzkumu a rozvoje vzdělávání, Myslíkova 7, 11000 Praha 1, e-mail: vit.stastny@pedf.cuni.cz

\section{Pregraduate Education and Professional Development of Teachers in China}

Abstract: A support of teachers as key actors of quality education for all is currently widely discussed global aim of the sustainable development. The aim of the study is to present the system of teacher education and their professional development in China, where a support of teachers is a political priority of the government. Methodologically, the study is based mostly on the desk-research and has descriptive analytical character, implicitly comparative. The paper focuses on the continuity of preparation and professional development analyzed on the national level with excursions to provincial and local levels. We concentrate on the structure and curriculum of pregraduate education and transition to practice, professional standards and career development, specifics of teacher activities in schools and cycles of evaluation. Finally, we reflect on characteristic approaches to teacher profession in specific conditions of culturally and typologically diverse education system in the context of educational reforms.

Key words: China, teachers, standards, reforms, quality of education 